PACS: 81.40.Jj

\title{
ELASTIC PROPERTIES OF ALLOY ZE10 SHEETS EVALUATION BY KERNS TEXTURE PARAMETERS
}

\author{
Valentin Usov ${ }^{a, *}$, (D) Natalia Shkatulyak ${ }^{a, \dagger}$, (D) Elena Savchuk ${ }^{b,+\dagger}$, Nadezhda Rybak ${ }^{a,+\dagger \dagger}$ \\ ${ }^{a}$ South Ukrainian National Pedagogical University named after K. D. Ushinsky \\ Str. Staroportofrankovskaya, 26, Odessa, 65020, Ukraine \\ ${ }^{b}$ National University "Odessa Maritime Academy", Str. Didrikhson, 8, Odessa, 65000, Ukraine \\ *Corresponding Author: E-mail address: valentinusov67@gmail.com

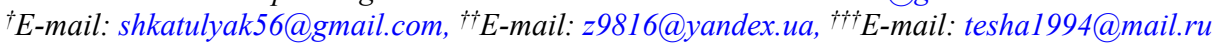

Received 18 December, 2020; accepted February 18, 2021

The ZE10 magnesium alloy with the rare-earth metal additives, which contribute to a better forming of the alloy, was used as studied
material. The ZE10 magnesium alloy with the rare-earth metal additives, which contribute to a better forming of the alloy, was used as
studied material. Sheet material is usually straightened on roller levelers to relieve residual stresses and improve flatness. The metal is
subjected to alternating deformation by bending when straightening. The changes in the structure, crystallographic texture and, as a
result, physical and mechanical properties occur in the metal are often not taken into account in the future. The elastic modulus is an
important parameter, for example, in the production of products using bending. In this work, the elastic modulus of sheets of magnesium
alloy ZE10 was estimated in three main directions. A starting sheet was obtained by extruding an ingot, then rolling in the longitudinal
direction and then rolling with a change in direction by $90^{\circ}$ after each pass in combination with heating to $350^{\circ} \mathrm{C}$. The original sheets
were subsequently subjected to alternate folding. Evaluations were made of the elastic modulus of the original sheet, as well as the
sheets after $0.5,1.0,3.0$ and 5.0 alternating bending cycles. To estimate the elastic modulus, we used the Kearns texture parameters,
which we calculated from the inverse pole figures, as well as the elastic constants of the single crystal of the ZE10 alloy found by us.
The maximum deviation of the calculated and experimental values of the elastic modulus did not exceed $5.2 \%$. Strong correlations and
quadratic regression equations have been established between the values of the elastic modulus, mechanical characteristics (tensile
strength, yield stress, elongation), on the one hand, and the above-mentioned parameters of the Kerns texture, on the other hand. The
approximation reliability coefficients are $0.76-0.99$.

KEYWORDS: magnesium alloy, alternating bending, Kearns texture parameters, elastic modulus, tensile strength, ultimate tensile strength, relative elongation

Magnesium, as the lightest metal suitable for the manufacture of structures, is the most attractive for use in the aviation and space industries [1]. However, the practical use of pure magnesium is difficult due to unsatisfactory forming during plastic deformation [1]. A crystallographic texture of the central basal type mainly is formed during rolling of $\mathrm{Mg}$, in which the crystallites are oriented with their hexagonal axis perpendicular to the rolling plane [2]. As a result, for example, during subsequent stamping or deep drawing, the material is destroyed. Therefore, in practice, structural materials are used not pure magnesium but magnesium-based alloys. In this case, aluminum, zinc, zirconium, lithium, as well as rare earth metals or less common metals (LCM) are used as alloying elements [3]. Such additives to magnesium in alloys contribute to an easier plastic flow of the metal during deformation due to an increase in the role of prismatic and pyramidal sliding and a decrease in the contribution of the basal one [4].

The alloy of magnesium with zinc, zirconium and rare earth metals ZE10 is one of the most promising for practical application of magnesium alloys. Before use, sheet material is usually straightened on roller straightening machines [5]. With such processing sheet or roll metal subjected to the alternating bending (AB) experiences periodic tensilecompression deformations. This helps to reduce residual stresses and favors the creation of a flat sheet [5]. Earlier it was shown that as a result of alternating bending, the original texture and, as a consequence, the physical and mechanical characteristics of the sheet are changed [6] that should be taken into account in the manufacture of products.

The alternating bending render most significant impact on the structural parameters and mechanical properties, which are sensitive to small deformations during tensile tests. These are texture, yield stress and twins $[6,7]$. The texture in $[6,7]$ was represented using inverse pole figures (IPF) of the direction (ND) to the rolling plane (IPF ND). The linear equations of regression with approximation reliability coefficients of at least 0.7 were established between the normalized values of pole density exceeding one on IPF ND, on the one hand, and values of the yield strength, ultimate tensile strength and elongation, averaged over all direction of the sheets, on the other hand $[6,7]$. At the same time, it seems more correct to compare the values of properties and texture characteristics measured in the same corresponding directions. The use of Kearns texture parameters allows carry out this comparison [8].

The Kearns texture parameters for materials with a hexagonal structure can be calculated both from their full direct pole figures, and from the inverse pole figures (IPF) of the corresponding directions in the sheet - normal direction (ND), rolling direction (RD), and transversal direction (TD) [8]. Moreover, knowledge of the Kearns texture parameters and the values of the properties of single crystals along and across the hexagonal axis allow calculating the tensor properties (for example, elasticity) of a polycrystalline sample in three mutually perpendicular directions [8]. 
This work aimed the Kearns texture parameters to find and evaluating on this base the elastic and mechanical properties of sheets of magnesium alloy ZE10 after industrial processing and subsequent alternating bending (AB). Such approach to evaluating of the elastic and mechanical properties of sheets of magnesium alloy ZE10 has not been used before.

\section{MATERIALS AND METHODS}

Sheets of ZE10 magnesium alloy ( $1.3 \% \mathrm{Zn}, 0.15 \% \mathrm{Zr}, 0.2 \%$ rare earth metals (REM), among REM mainly cerium) were obtained by processing [9], which consisted of ingot extrusion at a temperature of $350^{\circ} \mathrm{C}$, after which a slab $6 \mathrm{~mm}$ thick and $60 \mathrm{~mm}$ wide was obtained. Next, the slab was rolled sequentially in the longitudinal direction to a thickness of $4.5 \mathrm{~mm}$ in 2 passes in combination with heating to $350^{\circ} \mathrm{C}$ after each pass. Further rolling to a thickness of $2 \mathrm{~mm}$ was performed in the transverse direction in combination with heating to $350^{\circ} \mathrm{C}$ after each pass. The degree of deformation for each pass was approximately $10 \%$. From a thickness of $2 \mathrm{~mm}$, the direction of rolling was changed by $90^{\circ}$ after each pass with a degree of deformation of approximately $10 \%$ in combination with heating to $350^{\circ} \mathrm{C}$, and thus obtained sheets with a thickness of $1 \mathrm{~mm}$ (original sheets).

The alternating bending $(\mathrm{AB})$ was simulated on a manual bending device that included three rollers. The diameter of the bending roller was $50 \mathrm{~mm}$. The speed of metal movement during bending was $\sim 150 \mathrm{~mm} / \mathrm{s}$. The study was performed after $0.5 ; 1.0,3.0$ and 5.0 cycles. One cycle of alternating bending consisted of bending in one direction ( 0.25 cycles), straightening to a flat state $(0.5$ cycles $)$, bending in the other direction $(0.75$ cycles $)$ and straightening $(1.0$ cycle $)$.

The three series of samples for mechanical testing in every from the three direction namely rolling direction (RD), diagonal direction (DN, i. e. at an angle of $45^{\circ}$ to the $\mathrm{RD}$ ), and transverse direction (TD) were cut out from original sheet as well as from the sheets after bending for $0.5,1,3$ and 5 cycles. Mechanical tests of abovementioned samples were performed at room temperature on the tensile-testing machine Zwick Z250 / SN5A with a force sensor at $20 \mathrm{kN}$. The total length of the samples was $90 \mathrm{~mm}$. The length and width of the working part of the samples was $30 \mathrm{~mm}$ and $12.5 \mathrm{~mm}$, respectively.

For the Young's modulus measuring were cut out the samples through every $15^{\circ}$ from the rolling direction (RD) up to the transverse direction (TD) (by three samples in every direction) from original sheet as well as from the sheets after $\mathrm{AB}$. The length and width of the samples were respectively $100 \mathrm{~mm}$ and $10 \mathrm{~mm}$.

The Young's modulus was measured dynamically by the frequency of natural bending oscillations of flat specimens. The error Young's modulus measuring did not exceed 1\% [10].

The average value by three series of measured and tested specimens in each according direction were taken as values of the elastic and mechanical properties.

Samples to the texture study were cut also.

Before studying the texture, the samples were chemically polished to a depth of $0.1 \mathrm{~mm}$ to remove the distorted surface layer. The crystallographic texture was investigated on the two surfaces of the sheets, as well as in the rolling direction of the samples after above number of the RB cycles by means of the inverse pole figures (IPF) of the normal direction (ND IPF) and the rolling direction (RD IPF) on a DRON-3m diffractometer in filtered Ka-Mo X-ray. A typesetting sample was used to record of RD IPF. The sample without texture was made of fine recrystallized sawdust of the investigated alloy. Morris normalization was used in the construction of the IPFs [11].

\section{EXPERIMENTAL RESULTS AND DISCUSSION}

The experimental IPFs of the alloy under study are shown in Fig. 1. The texture of the initial sample of the ZE10 alloy (Fig. 1a,b) is characterized by a wide preferential scattering of normal's to the basal plane in the TD. The maximum deflection angle is $90^{\circ}$. Intermediate maxima of the deviation of the hexagonal prism from the ND are observed both towards the $\mathrm{TD}$ at $40^{\circ}$ and towards the $\mathrm{RD}$ by $40^{\circ}$, in contrast to the texture, which is usually formed in $\mathrm{Mg}$, $\mathrm{Ti}$, and $\mathrm{Zr}$.

Changes in the character of texture scattering are observed depending on the number of $\mathrm{AB}$ cycles (Fig. 1c - m). The pole density values on the IPFs change also. The observed changes in the pole density distribution at different stages of the $\mathrm{AB}$ indicate the occurrence of deformation processes of sliding and twinning $[6,7]$.

The Kearns texture parameters are often used to quantify the texture of hexagonal materials [8]. These coefficients, $f_{j}$ (index $j$ means the corresponding direction ND, RD or TD in the sample) show the degree of coincidence of the $c$-axes of the crystalline hexagonal cells of grains with a given geometric direction in a polycrystalline material and can be found by the IPFs according to the ratio

$$
f_{j}=\left\langle\cos ^{2} \alpha_{i}\right\rangle_{j}=\sum_{i} A_{i} P_{j i} \cos ^{2} \alpha_{i}
$$

where $P_{j i}=\frac{I_{i} / I_{R}}{\sum_{\Delta}\left(A_{i} \cdot I_{i} / I_{R}\right)} ; I_{i} / I_{R}$ is the ratio of the integral intensity of the $i$-th reflex on the $j$-th IPF to the corresponding value of the intensity of the reflex of the sample without texture $I_{R} ; A_{i}$ is statistical weights of the $i$-th reflex $\left(\sum A_{i} P_{j i}=1\right)[12]$. Conditionally $A_{i}$ determined by the fraction of the surface area of the stereographic triangle around 
the normal to the $i$-th reflex of the corresponding IPF; $\alpha_{i}$ is the angle of deviation from the $\mathrm{c}$ axis of the $i$-th crystallographic direction for the $j$-th direction in the sample.

For hexagonal single crystal, the value of some properties connecting two vector quantities or a tensor with a scalar quantity is determined [13] as:

$$
P(\varphi)_{r e f}=P_{c} \cos ^{2} \varphi+P_{a}\left(1-\cos ^{2} \varphi\right)
$$

Where $P(\varphi)_{\text {ref }}$ is property in the selected direction, $P_{a}$ and $P_{c}$ are the properties of a single crystal in a direction perpendicular and parallel to the direction[0002], respectively, $\varphi$ is the angle between the selected direction and [0002].
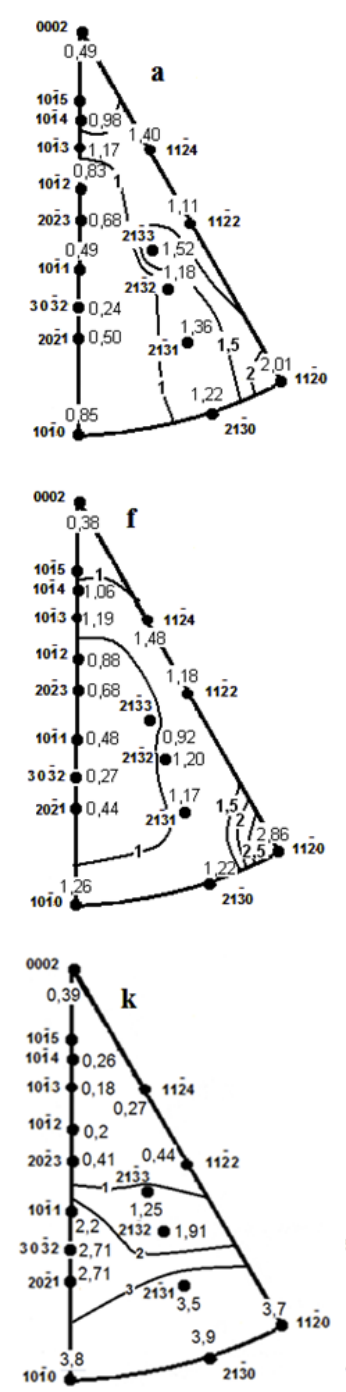
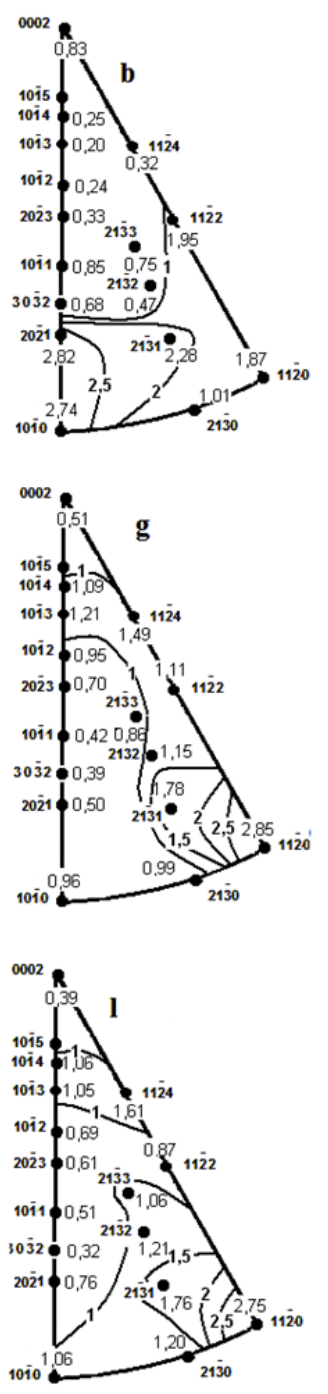
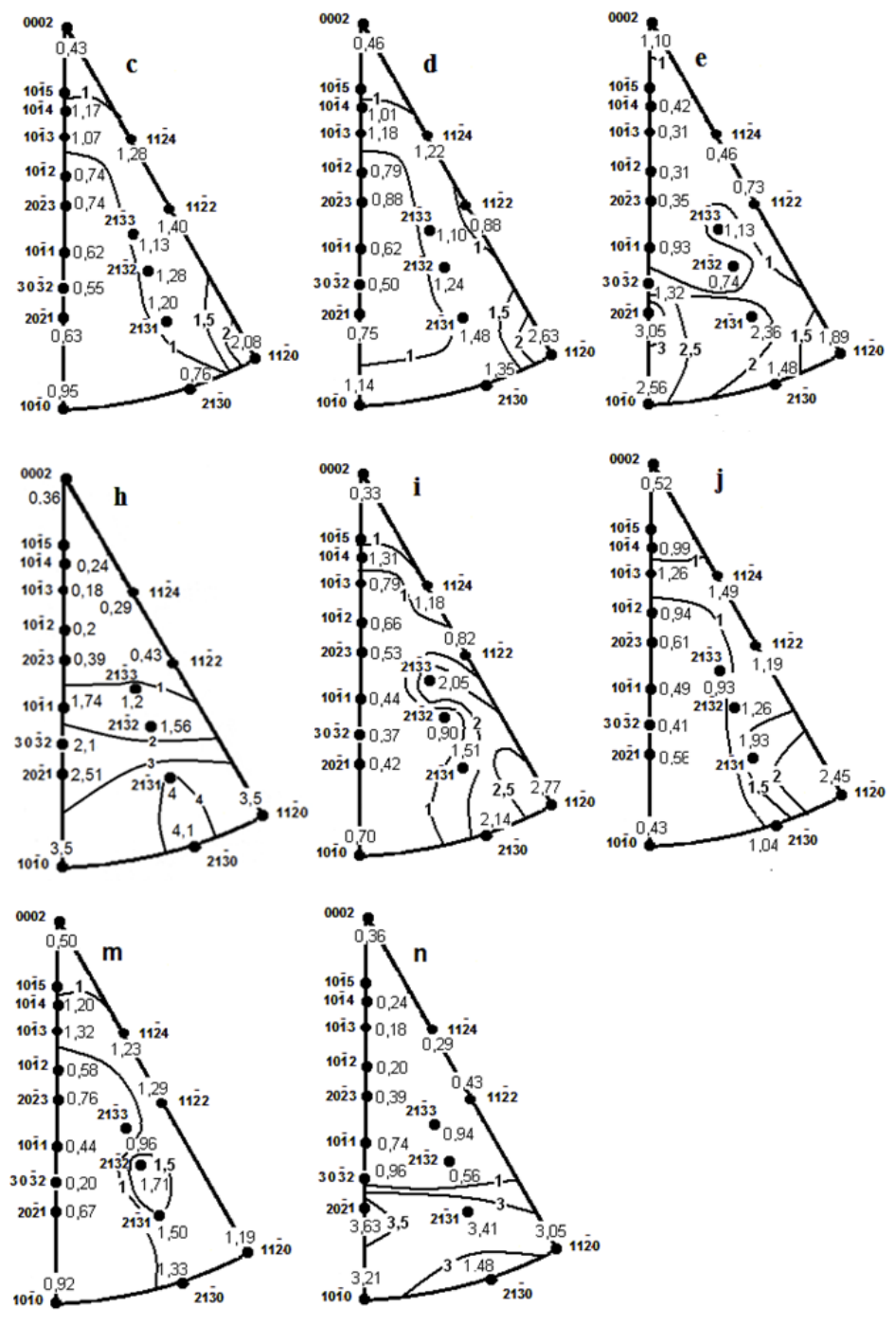

Figure 1. Experimental IPFs of the alloy ZE10: $(a, b)$ are IPFs of the original sheet; (c - e) are IPFs after 0.5 of the RB cycle; (f - h) are IPFs after 1 of the RB cycle; (i - k) are IPFs after 3 of the RB cycles; $(1-n)$ are IPFs after 5 of the RB cycles; (a, c, f, i, 1) are IPFs of $\mathrm{ND}$; (b, e, h, k, n) are IPFs of RD; (d, g, i, m) correspond to the stretched out sides of the sheets; (c, e, h, l) correspond to the compressed sides of the sheets

Assuming that crystallites in a polycrystalline contribute to the volumetric property in proportion to their volume fraction, $V_{i}$, the contribution to the volumetric property of crystals whose axes $c$ are oriented at an angle of inclination $\varphi$ to the chosen direction can be written in the form:

$$
P\left(\varphi_{i}\right)_{r e f}=P_{c} V_{i} \cos ^{2} \varphi_{i}+P_{a} V_{i}\left(1-\cos \varphi_{i}\right) .
$$

Summing over the entire volume, we get:

$$
P\left(\varphi_{i}\right)_{r e f}=P_{c} \sum_{i} V_{i} \cos ^{2} \varphi_{i}+P_{a} \sum_{i} V_{i}\left(1-\cos \varphi_{i}\right) .
$$


Since $\sum_{i} V_{i}=1$, and $\sum_{i} V_{i} \cos ^{2} \varphi_{i}=f_{j}$ is the Kearns texture parameter, we can write

$$
P\left(\varphi_{i}\right)_{r e f}=f_{j} P_{c}+\left(1-f_{j}\right) P_{a} .
$$

To find the Kearns texture parameters by formula (1), we used the IPFs in Fig. 1, the values of $A_{i}$ were taken from [12]. To calculate the angles between the crystallographic planes of a hexagonal single crystal using the known formulas [14], it is necessary to know the ratio of the crystal lattice parameters $c / a$ of the alloy under study. According to our data, for magnesium alloy ZE10 $(c / a)=1.622$. A similar result was also obtained by the authors of [15].

Kerns showed [8] that if a material property can be described by a tensor (for example, elasticity), then it obeys relation (5). In this case, the sum of $f_{j}$ in the three main directions of the sample should be equal to one and a value of $f_{j}=1 / 3$ in each direction determines the isotropic case. Thus, if the Kearns texture parameters found from ND IPF $\left(f_{N D}\right)$ and RD IPF $\left(f_{R D}\right)$ are known, then can find the Kearns parameter for the third direction in the sheet - the transverse direction (TD) - $f_{T D}$ by the ratio:

$$
f_{E D}+f_{T D}+f_{R D}=1
$$

The Kearns texture parameters calculated from ND IPF $\left(f_{N D}\right)$ and RD IPF $\left(f_{R D}\right)$ in Fig. 1 as well as $f_{T D}$ found using relation (6) are given in Table. 1.

Table 1. Kearns texture parameters

\begin{tabular}{|c|c|c|c|c|c|}
\hline \multirow{2}{*}{ Cycles number, $\mathrm{n}$} & \multicolumn{5}{|c|}{ Kearns texture parameters } \\
\cline { 2 - 6 } & $f_{N D}^{(1)}$ & $f_{N D}^{(2)}$ & $f_{N D}^{(a v)}$ & $f_{R D}$ & $f_{T D}$ \\
\hline 0 & 0.340 & 0.340 & 0.340 & 0.176 & 0.484 \\
\hline 0.5 & 0.322 & 0.324 & 0.323 & 0.203 & 0.474 \\
\hline 1.0 & 0.322 & 0.318 & 0.320 & 0.208 & 0.472 \\
\hline 3.0 & 0.326 & 0.306 & 0.316 & 0.217 & 0.467 \\
\hline 5.0 & 0.323 & 0.315 & 0.319 & 0.153 & 0.528 \\
\hline
\end{tabular}

Analysis of the distribution of pole density on the ND IPFs of opposite sides of the sheets after a different number cycles of AB showed certain inconsistencies (Fig. 1, c, d; f, g; i, j; 1, m). The cause of these discrepancies is due to the fact that when bent to one side, the metal layers on the convex side of the sheet are subjected to tensile deformation. At the same time, the corresponding metal layers on the concave side of the sheet are deformed by compression. The deformation processes are alternated when the sign of bending is periodical changed. Similar inconsistencies in the distribution of the pole density on the IPFs of the outer and inner sides of the strips obtained after cutting along the axis and subsequent straightening of the tube made of $\mathrm{Zr}-2.5 \% \mathrm{Nb}$ alloy were found earlier in [16].

The noted inconsistencies are reflected on the values of the Kearns texture parameters, calculated from the ND IPFs of opposite sides of the sheets after the $\mathrm{AB}\left(f_{N D}^{(1)}\right.$, and $f_{N D}^{(2)}$, Table 1). For further analysis of the $\mathrm{AB}$ effect on the properties of investigated alloy in the ND to the sheets plane were used of the Kearns texture parameters averaged over both sides of the sheets after the corresponding number of $\mathrm{AB}$ cycles.

The values of the modulus of elasticity, measured every $15^{\circ}$ in the rolling plane of the sheets of investigated alloy, are presented in Table 2 .

Tables 3-5 show the experimental values of ZE10 alloy mechanical characteristics: ultimate tensile strength $\sigma_{U T S}$, yield strength $\sigma_{Y S}$ and relative elongation $\varepsilon=\Delta l / l$.

Table 2. Experimental elastic modulus $E_{\text {exp }}$ after alternating bending of ZE10 alloy sheets

\begin{tabular}{|c|c|c|c|c|c|}
\hline \multirow{2}{*}{$\begin{array}{c}\text { Angle with the } \\
\text { RD, deg. }\end{array}$} & \multicolumn{5}{|c|}{ Elastic modulus $E_{\text {exp }}, \mathrm{GPa}$} \\
\cline { 2 - 6 } & 0 & 0.5 & 1.0 & 3.0 & 5.0 \\
\hline 0 & 46.3 & 46.0 & 45.8 & 45.0 & 44.8 \\
\hline 15 & 44.3 & 44.0 & 43.8 & 43.5 & 43.7 \\
\hline 30 & 43.5 & 43.1 & 43.0 & 43.1 & 42.8 \\
\hline 45 & 43.1 & 43.0 & 42.8 & 42.7 & 42.5 \\
\hline 60 & 43.3 & 43.2 & 43.0 & 42.5 & 42.5 \\
\hline 75 & 43.6 & 43.5 & 43.1 & 43.0 & 42.8 \\
\hline 90 & 43.9 & 43.8 & 43.0 & 43.3 & 43.3 \\
\hline
\end{tabular}


Table 3. Ultimate tensile strength $\sigma_{U T S}$ after alternating bending of ZE10 alloy sheets

\begin{tabular}{|c|c|c|c|c|c|}
\hline \multirow{2}{*}{$\begin{array}{c}\text { Angle with the } \\
\text { RD, deg. }\end{array}$} & \multicolumn{5}{|c|}{ Ultimate tensile strength $\sigma_{\text {UTS }}, \mathrm{MPa}$} \\
\cline { 2 - 6 } & 0 & 0.5 & 1.0 & 3.0 & 5.0 \\
\hline 0 & 246.0 & 250.0 & 252.0 & 256.0 & 250.0 \\
\hline 45 & 231.0 & 219.0 & 219.0 & 221.0 & 229.0 \\
\hline 90 & 216.0 & 221.0 & 225.0 & 234.0 & 214.0 \\
\hline
\end{tabular}

Table 4. Yield strength $\sigma_{Y S}$ after alternating bending of ZE10 alloy sheets

\begin{tabular}{|c|c|c|c|c|c|}
\hline \multirow{2}{*}{$\begin{array}{c}\text { Angle with the } \\
\text { RD, deg. }\end{array}$} & \multicolumn{5}{|c|}{ Yield strength $\sigma_{Y S}, \mathrm{MPa}$} \\
\cline { 2 - 6 } & 0 & 0.5 & 1.0 & 3.0 & 5.0 \\
\cline { 2 - 6 } & 174.0 & 174.0 & 102.0 & 89.0 & 173.0 \\
\hline 0 & 132.0 & 99.0 & 88.0 & 100.0 & 89.0 \\
\hline 45 & 91.0 & 88.0 & 89.0 & 91.0 & 96.0 \\
\hline 90 & &
\end{tabular}

Table 5. Relative elongation $\varepsilon=\Delta l / l$ after alternating bending of ZE10 alloy sheets

\begin{tabular}{|c|c|c|c|c|c|}
\hline \multirow{2}{*}{$\begin{array}{c}\text { Angle with the RD, } \\
\text { deg. }\end{array}$} & \multicolumn{5}{|c|}{ Relative elongation $\varepsilon=\Delta l / l, \%$} \\
\cline { 2 - 6 } & 0 & 0.5 & 1.0 & 3.0 & 5.0 \\
\hline 0 & 23.1 & 21.0 & 20.5 & 19.1 & 28.3 \\
\hline 45 & 28.0 & 36.1 & 19.1 & 35.6 & 25.0 \\
\hline 90 & 33.4 & 32.6 & 33.0 & 31.0 & 34.3 \\
\hline
\end{tabular}

Let us estimate the value of the elasticity modulus of the alloy under study in three directions of the sheets: RD, TD and ND. For this we are used the Kerns texture parameters (Table 1) and the single crystal elastic constants of the alloy under study. Earlier in [17], we found the values of the elastic constant $S_{11}$ and the combination of the elastic constants

According to [17]

$$
\begin{gathered}
a=S_{13}-S_{11}+0.5 S_{44}, \\
b=S_{11}+S_{33}-2 S_{13}-S_{44} .
\end{gathered}
$$

$$
\left(S_{11}=2.287 ; a=-0.100 ; b=0.128\right) \cdot 10^{-11} \mathrm{~Pa}^{-1} .
$$

Simple transformations of relations (7) - (9) made it possible to calculate the elastic constant of $S_{33}=2.22 \cdot 10^{-11} \mathrm{~Pa}^{-1}$.

A relation was obtained in [18] that makes it possible to express the elastic modulus in terms of the Miller indices, the ratio $c / a$, and the elastic constants of a hexagonal single crystal:

$$
E(h k l)=\frac{\left[h^{2}+\frac{(h+2 k)^{2}}{3}+\left(\frac{a}{c} l\right)^{2}\right]}{\left[S_{11}\left(h^{2}+\frac{(h+2 k)^{2}}{3}\right)^{2}+S_{33}\left(\frac{a}{c} l^{4}\right)+\left(S_{44}+2 S_{33}\right)\left(h^{2}+\frac{(h+2 k)^{2}}{3}\right)\left(\frac{a}{c} l\right)^{2}\right]} .
$$

As a result of substitution of the corresponding quantities of $S_{11}, S_{33}, h, k, l, c$, and $a$ into relation (10), we obtain that

$$
\begin{gathered}
E(001)=E_{C}=\frac{1}{S_{33}}=45.147 \mathrm{GPa} \\
E(100)=E(110)=E_{a}=\frac{1}{S_{11}}=43.730 \mathrm{GPa}
\end{gathered}
$$

Now let us estimate the value of the elastic modulus of the sheets of the investigated alloy in three directions of the sheet $E_{R D}, E_{T D}$, and $E_{N D}$ by a relation of the type (8), using the values of the elastic modulus of the single crystal along and across the hexagonal axis of the ZE10 alloy (11) and (12), as well as the corresponding of the Kerns texture parameters (Table 1). The calculation results are presented in the Table 6. The experimental values of the modulus of elasticity for 
convenience of comparison are also given in the Table 6. It is seen that the maximum deviation of the calculated and experimental values of the elastic modulus was $5.2 \%$.

We could not experimentally measure the elastic modulus in the normal direction $E_{N D}$ to the rolling plane due to the small sheet thickness $(1 \mathrm{~mm})$. The value of the $E_{N D}$ in the original sheet of the ZE10 alloy estimated earlier us in [16] was $43.8 \mathrm{GPa}$. The value of the $E_{N D}$ obtained in this work (Table 6) deviates from the above value by $0.9 \%$ (Table 6 ).

Unfortunately, it is impossible to estimate the value of the mechanical characteristics of the alloy under study using the Kearns texture parameters, similar to the above calculations for the elastic modulus, since data on the strength and plastic properties of the single crystal of the alloy ZE10 are missed in the literature.

Table 6. Experimental and calculated elastic modulus after alternating bending of ZE10 alloy sheets

\begin{tabular}{|c|c|c|c|c|c|c|c|}
\hline $\begin{array}{c}\text { Number of the } \\
\mathrm{AB} \text { cycles, } \mathrm{n}\end{array}$ & $E_{R D}^{\text {exp }}, \mathrm{GPa}$ & $E_{R D}^{\text {calc }}, \mathrm{GPa}$ & $\Delta E / E_{\text {exp }} \%$ & $E_{T D}^{\text {exp }}, \mathrm{GPa}$ & $E_{T D}^{\text {calc }}, \mathrm{GPa}$ & $\Delta E / E_{\text {exp }}, \%$ & $E_{N D}^{\text {calc }}, \mathrm{GPa}$ \\
\hline 0 & 46.3 & 43.9 & 5.2 & 43.9 & 44.4 & -1.1 & 44.2 \\
\hline 0.5 & 46.0 & 44.0 & 4.3 & 43.8 & 44.4 & -1.4 & 44.2 \\
\hline 1.0 & 45.8 & 44.0 & 3.9 & 43.5 & 44.0 & -1.1 & 44.2 \\
\hline 3.0 & 45.0 & 44.1 & 2.0 & 43.3 & 44.4 & -2.5 & 44.2 \\
\hline 5.0 & 44.8 & 44.0 & 1.8 & 43.3 & 44.5 & -2.8 & 44.2 \\
\hline
\end{tabular}

It is known that one of the main causes for the appearance of anisotropy in the physical and mechanical properties of polycrystalline metallic materials is the crystallographic texture formed during deformation. As mentioned above, Kearns texture parameters are often used to quantify the texture of hexagonal materials [19].

Let us analyze the observed changes in the studied characteristics (Tables 2-5) in connection with the crystallographic texture, represented by the Kearns texture parameters (Table 1). The analysis was showed that there are strong correlations between the values of the modulus of elasticity, mechanical characteristics, on the one hand, and the above-mentioned Kearns texture parameters, on the other hand. The corresponding regression equations and approximation reliability coefficients are represented by the relations (13) - (20):

$$
\begin{gathered}
E_{R D}^{\exp }=-1514.6 f_{R D}^{2}+563.9 f_{R D}-6.0 ; R^{2}=0.99 \\
E_{T D}^{\exp }=-846,2 f_{T D}^{2}+841.4 f_{T D}-165.1 ; R^{2}=0.90 \\
\sigma_{Y S R D}^{\exp }=-48102.0 f_{R D}^{2}+16566.0 f_{R D}-1239.5 ; R^{2}=0.76 \\
\sigma_{Y S T D}^{\exp }=2047.1 f_{T D}^{2}+1932.7 f_{T D}+545.8 ; R^{2}=0.84 \\
\sigma_{U T S R D}^{R D}=4640.5 f_{R D}^{2}-1584.7 f_{R D}+381.0 ; R^{2}=0.99 \\
\sigma_{U T S R D}^{\exp }=17176.0 f_{T D}^{2}-17387.0 f_{T D}+4606.3 ; R^{2}=0.94 \\
\varepsilon_{R D}^{\exp }=1437.3 f_{R D}^{2}-664.0 f_{R D}+96.0 ; R^{2}=0.98 \\
\varepsilon_{T D}^{\exp }=-1916.6 f_{T D}^{2}+1952.8 f_{T D}-462.5 ; R^{2}=0.84
\end{gathered}
$$

\section{CONCLUSION}

The crystallographic texture of the original sample of polycrystalline magnesium alloy ZE10 after ingot extrusion, further rolling in the longitudinal direction and subsequent rolling with a direction change by $90^{\circ}$ after each pass in combination with heating to $350^{\circ} \mathrm{C}$ is characterized by a wide predominant scattering of normal's to the basal plane in the TD with a maximum angle deviations of $90^{\circ}$ and intermediate maxima of the deviation of the hexagonal prism from the ND both towards the TD by $40^{\circ}$ and towards the RD by $40^{\circ}$, in contrast to the texture, which is usually formed in $\mathrm{Mg}$, Ti and Zr.

Inconsistencies in the distribution of pole density on the ND IPF after a different number cycles of alternating bending are caused by alternating deformation by stretching and compression, respectively, on the convex and concave sides of the sheets results to a mismatch of the Kearns texture parameters, which were calculated from the ND IPF of opposite sides of the sheets.

Evaluations of the elastic modulus in three main directions of the original sheet of magnesium alloy ZE10, as well as sheets after $0.5 ; 1.0 ; 3.0$; and 5.0 cycles of alternating bending were carried out using the Kearns texture parameters and the elastic constants of the alloy single crystal. The maximum deviation of the calculated and experimental values does not exceed $5.2 \%$. 
Strong correlations the elastic modulus and mechanical characteristics values with Kearns texture parameters established and quadratic regression equations with approximation reliability coefficients of $0.76-0.99$ were found.

The presented results may be useful to develop a technology for obtaining improved characteristics of the shaping and minimal anisotropy of mechanical characteristics of magnesium alloys sheets.

\section{ORCID IDs}

DValentin Usov, https://orcid.org/0000-0001-7855-5370; (D) Nataliia Shkatulyak, https://orcid.org/0000-0003-4905-001X

(D) Elena Savchuk, https://orcid.org/0000-0002-4249-6505

\section{REFERENCES}

[1] M. Millikin, https://www.greencarcongress.com/2018/01/20180131-epfl.html

[2] J. Wu, L. Jin, J. Dong, F. Wang, and S. Dong, J. Materials Science \& Technology, 42, 175-189 (2020), https://doi.org/10.1016/j.jma.2013.02.002

[3] B. Prasad, and P.P. Bhingole, Advanced Materials Proceedings, 2(11), 734-744 (2017), https://doi.org/10.5185/amp.2017/859, https://www.vbripress.com/amp/articles/fullArticle-pdf/203

[4] K.K. Alaneme, and E.A. Okotete, J. of Magnesium and Alloys, 5, 460-475 (2017), https://doi.org/10.1016/j.jma.2017.11.001

[5] ARKU Inc., 7251 E. Kemper Road, Cincinnati, OH 45249, https://www.arku.com/us/arku-magazine/detail/sheet-metal-levelingmethods-us/

[6] N.M. Shkatulyak, V.V. Usov, N.A. Volchok, et. al, The Physics of Metals and Metallography, 115(6) 609-616 (2014), https://link.springer.com/article/10.1134/S0031918X1406012X

[7] N.M. Shkatulyak, S.V. Smirnova, and V.V. Usov, International Journal of Metals, 2015, Article ID 349810 (2015), https://doi.org/10.1155/2015/349810.

[8] J.J. Kearns, https://ntrl.ntis.gov/NTRL/dashboard/searchResults/titleDetail/WAPDTM472.xhtml

[9] WIPO Patent Application WO/2011/146970, http://www.sumobrain.com/patents/wipo/Magnesium-based-alloy-wroughtapplications/WO2011146970A1.html

[10] Standard Test Method for Dynamic Young's Modulus, Shear Modulus, and Poisson's Ratio by Impuls Excitation of Vibration, http://forlab.pt/wp-content/uploads/2015/08/E1876_mvuj8965.pdf

[11] P.R. Morris, Journal of Applied Physics, 30(4), 595-596 (1959), https://aip.scitation.org/doi/10.1063/1.1702413

[12] N.V. Ageev, A.A. Babareko, and S.Ya. Betsofen, Izv. Ross. Akad. Nauk, Ser. Met., 1, 94-103 (1974). [in Russian]

[13] J.F. Nye, Physical properties of crystals their representation. Their representation by tensors and matrices, (Oxford: University Press, 2006), pp. 131-149, http://93.174.95.29/main/7258F1CE1EEE4CD628566F4EA21CDD58

[14] C. Tannous, https://hal.archives-ouvertes.fr/hal-02268849v2/document

[15] Y. Liu, W. Li, and Y. Li, International Journal of Minerals, Metallurgy and Material, 16(5), 559-563 (2009), https://doi.org/10.1016/S1674-4799(09)60096-0

[16] V. Grytsyna, D. Malykhin, T. Yurkova, K. Kovtun, T. Chernyayeva, G. Kovtun, I. Tantsura, and V. Voyevodin, East Eur. J. Phys. 3, 38-45 (2019), https://doi.org/10.26565/2312-4334-2019-3-05

[17] S.V. San'kova, N.M. Shkatulyak, V.V. Usov, and N.A. Volchok, Article ID 142920, 6 pages, (2014), https://www.hindawi.com/journals/ijmet/2014/142920/

[18] J.-M. Zhang, Y. Zhang, K.-W. Xu, and V. Ji, Thin Solid Films, 515, 7020-7024 (2007), https://doi.org/10.1016/j.tsf.2007.01.045.

[19] J.J. Kearns, Journal of Nuclear Materials, 299(2), 171-174 (2001), https://doi.org/10.1016/S0022-3115(01)00686-9

\section{ОЦІНКА ПРУЖНИХ ВЛАСТИВОСТЕЙ ЛИСТІВ СПЛАВА ZЕ10 ЗА ПАРАМЕТРАМИ ТЕКСТУРИ КЕRNS}

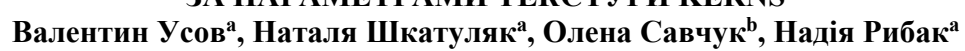

"Південноукрайнський начіональний педагогічний університет імені К.Д. Уиинського вул. Старопортофранківська, 26, Одеса 65020, Украйна

${ }^{b}$ Національний університет «Одеська морська академія», вул. Дідріхсона, 8, Одеса 65000, Украйна

Матеріалом для дослідження послужив сплав ZE10 магнію з добавками рідкісноземельних металів, які сприяють кращої формозміни сплаву. Листовий матеріал після прокатки зазвичай випрямляють на роликових правильних машинах для зняття залишкових напружень і поліпшення площинності. В процесі правки метал піддається знакозмінної деформації вигином. Не дивлячись на незначну деформацію в процесі правки, в металі відбувається помітні зміни структури, кристалографічної текстури i, як наслідок, фізико-механічних властивостей, що часто не враховується в подальшому. Модуль пружності $\epsilon$ важливим параметром, наприклад, при виробництві виробів за допомогою гнуття. У даній роботі нами була проведена оцінка модуля пружності листів магнієвого сплаву ZE10 за трьома основними напрямками. Вихідний лист був отриманий шляхом екструзії злитка, подальшим вальцюванням в поздовжньому напрямку та наступним вальцюванням зі зміною напрямку вальцювання на $90^{\circ}$ після кожного проходу в поєднанні з нагріванням до $350^{\circ} \mathrm{C}$. Вихідні листи в подальшому піддавалися знакозмінному вигину. Нами були проведені оцінки модулів пружності вихідного листа, а також листів після 0,5, 1,0, 3,0 і 5,0 циклів знакозмінного вигину. Для оцінки модуля пружності використані параметри текстури Кернса, розраховані нами зі зворотних полюсних фігур, а також знайдені нами пружні постійні монокристала сплаву ZE10. Максимальне відхилення розрахункових і експериментальних значень модуля пружності не перевищувало 5,2 \%. Нами було встановлено сильні кореляційні зв'язки та квадратні рівняння регресії між значеннями модуля пружності, механічних характеристик (межа міцності, границя текучості, відносне подовження), з одного боку, і згаданими вище параметрами текстури Кернса, з іншого боку. Коефіцієнти надійності апроксимації склали 0,76 - 0,99.

КЛЮЧОВІ СЛОВА: магнієвий сплав, знакозмінний вигин, параметри текстури Кернса, модуль пружності, межа міцності при розтягуванні, межа плинності при розтягуванні, відносне подовження. 